\title{
Biomass allometric equation and expansion factor for a mountain moist evergreen forest in Mozambique
}

\author{
Sá Nogueira Lisboa*, Benard Soares Guedes, Natasha Ribeiro and Almeida Sitoe
}

\begin{abstract}
Background: Worldwide, forests are an important carbon sink and thus are key to mitigate the effects of climate change. Mountain moist evergreen forests in Mozambique are threatened by agricultural expansion, uncontrolled logging, and firewood collection, thus compromising their role in carbon sequestration. There is lack of local tools for above-ground biomass (AGB) estimation of mountain moist evergreen forest, hence carbon emissions from deforestation and forest degradation are not adequately known. This study aimed to develop biomass allometric equations (BAE) and biomass expansion factor (BEF) for the estimation of total above-ground carbon stock in mountain moist evergreen forest.

Methods: The destructive method was used, whereby 39 trees were felled and measured for diameter at breast height $(D B H)$, total height and the commercial height. We determined the wood basic density, the total dry weight and merchantable timber volume by Smalian's formula. Six biomass allometric models were fitted using non-linear least square regression. The BEF was determined based on the relationship between bole stem dry weight and total dry weight of the tree. To estimate the mean AGB of the forest, a forest inventory was conducted using 27 temporary square plots. The applicability of Marzoli's volume equation was compared with Smalian's volume equation in order to check whether Marzoli's volume from national forest inventory can be used to predict AGB using BEF.
\end{abstract}

Results: The best model was the power model with only $D B H$ as predictor variable, which provided an estimated mean AGB of $291 \pm 141 \mathrm{Mg} \mathrm{ha}^{-1}$ (mean $\pm 95 \%$ confidence level). The mean wood basic density of sampled trees was $0.715 \pm 0.182 \mathrm{~g} \mathrm{~cm}^{-3}$. The average BEF was of $2.05 \pm 0.15$ and the estimated mean AGB of $387 \pm 126 \mathrm{Mg} \mathrm{ha}^{-1}$. The BAE from miombo woodland within the vicinity of the study area underestimates the AGB for all sampled trees. Chave et al.'s pantropical equation of moist forest did not fit to the Moribane Forest Reserve, while Brown's equation of moist forest had a good fit to the Moribane Forest Reserve, having generated 1.2\% of bias, very close to that generated by the selected model of this study. BEF showed to be reliable when combined with stand mean volume from Marzoli's National Forestry Inventory equation.

Conclusion: The BAE and the BEF function developed in this study can be used to estimate the AGB of the mountain moist evergreen forests at Moribane Forest Reserve in Mozambique. However, the use of the biomass allometric model should be preferable when DBH information is available.

Keywords: Above-ground tree biomass, Carbon stock, Pan-tropical equation, Biomass expansion factor

\footnotetext{
*Correspondence: sanogueiralisboa@gmail.com
}

Department of Forestry, Faculty of Agronomy and Forestry Engineering,

Eduardo Mondlane University, Main Campus, Building \# 1, P.O.Box 257,

Maputo, Mozambique

(c) The Author(s) 2018. This article is distributed under the terms of the Creative Commons Attribution 4.0 International License (http://creativecommons.org/licenses/by/4.0/), which permits unrestricted use, distribution, and reproduction in any medium, provided you give appropriate credit to the original author(s) and the source, provide a link to the Creative Commons license, and indicate if changes were made. 


\section{Introduction}

Forests generally, and moist tropical forests specifically, have huge amounts of carbon in their biomass [1]. This means that tropical forest vegetation, which accounts for about $50 \%$ of the world's forest, store not less than $46 \%$ of the world's living terrestrial carbon pool, and the tropical soils store about $11.55 \%$ of the world's soil carbon pool $[2,3]$. Mountain moist evergreen forests cover a small part (less than 3\%) of the total forest area in Mozambique $\left(400,680 \mathrm{~km}^{2}\right)$ [4], and typical examples can be found in the Chimanimani outskirts, where Moribane Forest Reserve (MFR) is located $[4,5]$. In fact, the MFR is among the largest moist evergreen forests in Mozambique [4]. The flora of these forests is still poorly known, but includes some of the locally threatened or endemic plant species [6].

In spite of still containing high species richness and diversity of plants and animals $[6,7]$, the MFR is at risk of deforestation and forest degradation (D\&FD) [8]. Therefore, disturbance and land use can thus have large impacts on carbon emission into the atmosphere [1]. A case study carried in the Manica province, which included the MFR area, has observed annual biomass and carbon losses of 3.1\% (2007-2010), attributable equally to D\&FD [8]. The D\&FD has resulted in negative impacts on biodiversity conservation and climate change $[6,9]$.

Solutions to reverse or slow down D\&FD in MFR include improving forest carbon storage, protecting biodiversity, and sustaining livelihoods of forest-dependent people. This includes the implementation of emerging carbon credit market mechanisms such as Reducing Emissions from Deforestation and Forest Degradation $($ REDD +$)$ [10]. Mountain moist evergreen forests have a great potential for conservation within the REDD+ context because they store large amounts of carbon, they have high biodiversity level and socio-ecological value [7, 8].

The Paris Agreement encourages developing countries to contribute to climate change mitigation by reducing emissions from deforestation, forest degradation, conserving carbon stocks, managing forest sustainably and enhancing forest carbon stocks [11]. With the REDD+ centered on results-based mechanism, where carbon is the most important result indicator, the need to establish appropriate allometric models and biomass expansion factor (BEF) has grown. Although information on biomass allometric equations (BAE) has been developed for African forests, little has been done for moist evergreen forests, particularly those in Mozambique [12].

So, for countries that need to implement the REDD+ mechanism, it is important to develop biomass local models and parameters per forests types to estimate accurately the greenhouse gas emissions from D\&FD
[13]. Appropriate BAE and BEF and reliable forest inventory data on biomass is essential to accurately quantify, monitor and report the impacts or benefits of REDD+ activities on climate change mitigation [13, 14]. BEF has been particularly useful because need aggregated data (mostly mean stand volume) from forest inventories in order to estimate average above-ground tree biomass. Therefore, it becomes very useful when stand volume of forest inventory is available but not only the individual trees as required by allometric model [14].

However, BAE and BEF functions previously developed in Mozambique were developed for forest types other than moist evergreen forest, e.g. lowland miombo woodland [15-17], mangrove forests [18] and mecrusse woodlands [19-21]. Moreover, the degree of reliability of the existing general allometric models and BEF functions and those suggested for moist in tropical zones [2, 22-24] must be checked if applied in a site different than that where they were originally developed [25].

In this study, we develop a pioneer BAE and a BEF for estimating total (stem, branches and foliage) aboveground tree biomass (AGB) of mountain moist evergreen forest in MFR, in central Mozambique. BEF function is intended to estimate total AGB using the wood volume and wood basic density [14, 22], which are provided by the national forest inventory [4].

\section{Materials and methods}

\section{Study area}

This study was carried out at Moribane Forest Reserve (MFR), located in the district of Sussundenga in central Mozambique (S $19^{\circ} 45^{\prime}, 33^{\circ} 22^{\prime} \mathrm{E}$ ) (Fig. 1). The MFR has a total area of about $53 \mathrm{~km}^{2}$ and was proclaimed as a conservation area in 1957 [26]. Since 2000, the MFR is part of the Chimanimani Transfrontier Conservation Area, which involves Mozambique and Zimbabwe. Extensive forest perturbance was caused in some parts of the forest by a devastating fire which occurred in 1992, subsequent to a very severe drought [6]. Sussundenga district had a population of 168 thousand in 2017 [27]. Artisanal mining in the highlands, deforestation for slash-andburn agriculture, illegal hunting and logging are the main threats of biodiversity loss in MFR [28]. Ryan et al. [8] stated that within the MFR, biomass was lost at a rate of $2.8 \pm 1.9 \%$ per year, with stocks changing from $19.4 \pm 0.9$ $\mathrm{TgC}$ in 2007 to $17.6 \pm 0.9 \mathrm{TgC}$ in 2010 . Small-scale agriculture was the direct cause of $46 \pm 17 \%$ of the total biomass loss, followed in magnitude by construction and miscellaneous activities $(24 \pm 11 \%)$, charcoal production $(18 \pm 9 \%)$, logging $(9 \pm 5 \%)$ and commercial agriculture $(3 \pm 2 \%)[8]$.

The moist evergreen forest is the main forest type of MFR, which is dominated by evergreen tree species and 


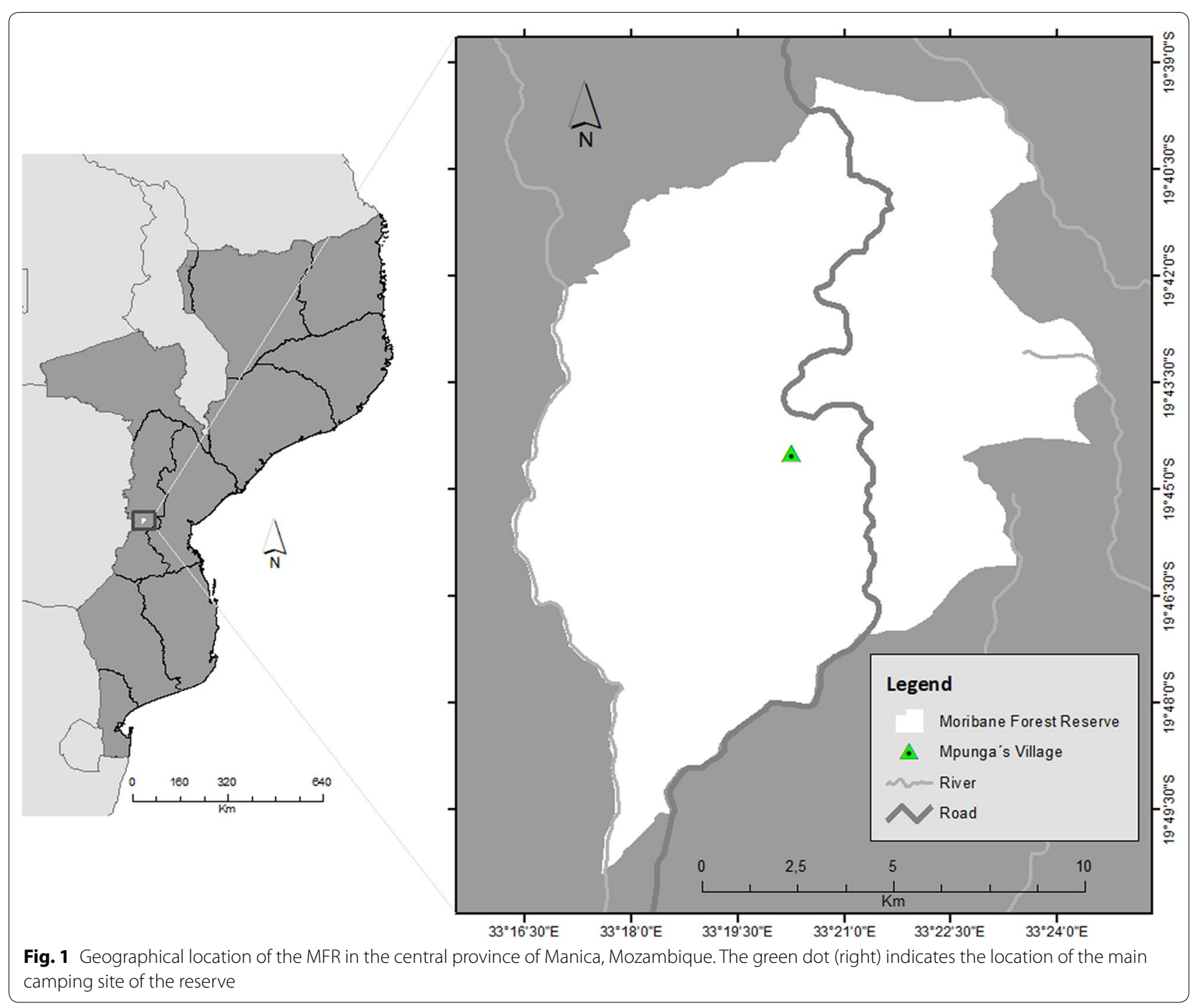

deciduous tree species, such as Newtonia buchananii (Baker) Gilbert \& Boutique (Leguminosae), Pteleopsis myrtifolia (M. A. Lawson) Engl. \& Diels (Combretaceae), Millettia stuhlmannii Taub. (Leguminosae), Albizia gummifera (J. F. Gmel.) C. A. Sm. (Leguminosae), Khaya anthotheca (Welw.) C. DC., among others [4, 6, 26, 29, 30]. The climate is classified as tropical, modified by altitude, according to Köppen climate classification [31]. The altitude range is $400-550 \mathrm{~m}$ a.s.l., the mean annual temperature range is $17-24{ }^{\circ} \mathrm{C}$ [30]. The mean annual rainfall range is $1200-1400 \mathrm{~mm}$ [29], and the soils range from sandy loam to sandy clay [32].

\section{Forest inventory and assessment of total above-ground tree biomass}

A conventional forest inventory was carried on 27 square non-permanent inventory plots, $50 \times 50 \mathrm{~m}$ (0.25 ha). At each sampling plot, diameter at breast height $(D B H$ at $1.3 \mathrm{~m}$ from the ground), commercial tree height $(\mathrm{HC})$, and total tree height $(T H)$ were measured on all trees and shrubs with $\mathrm{DBH} \geq 5 \mathrm{~cm}$. All trees were identified at species level in the field by a skilled botanist. Total (stem, branches and foliage) AGB was estimated using the destructive method. Field sampling resulted in a total of 39 trees (Table 1), which were used to construct the BAE for the MFR. The trees for destructive sampling were selected randomly in the landscape considering the need to represent size classes of DBH from 5 to $60 \mathrm{~cm}$. However, the national legislation does not allow any logging activities inside conservation areas in Mozambique. With this limitation, the sample trees were cut in the buffer zone of MFR, where human disturbance is high. Hence, some trees sized between 40 and $50 \mathrm{~cm}$ were not sampled. 
Table 1 Descriptive statistics of the trees sampled used to construct the BAE and to determine the biomass expansion factor at the MFR in Mozambique

\begin{tabular}{lrrl}
\hline Variables and parameters & \multicolumn{3}{l}{ Description } \\
\cline { 2 - 4 } & Mean & \multicolumn{1}{c}{ SE } & Range \\
\hline DBH $(\mathrm{cm})$ & 21.46 & 12.84 & \multicolumn{1}{l}{$5.50-57.00$} \\
Total tree height $(\mathrm{m})$ & 12.26 & 4.43 & $4.72-23.80$ \\
Commercial tree height $(\mathrm{m})$ & 5.14 & 2.77 & $1.40-10.60$ \\
Smalian's stem volume $\left(\mathrm{m}^{3}\right)$ & 0.27 & 0.36 & $0.0072-1.58$ \\
Wood basic density $\left(\mathrm{g} \mathrm{cm}^{-3}\right)$ & 0.71 & 0.16 & $0.46-0.91$ \\
Total dry weight $\left(\mathrm{kg} \mathrm{tree}^{-1}\right)$ & 523.12 & 843.42 & $3.96-3539.06$
\end{tabular}

$S E$ is standard error of the mean

The DBH of the selected trees was measured using a caliper, whereas the commercial and total tree height/ length were measured using a conventional measuring tape after the tree has been fallen. Each sampled tree was divided into three components (i) bole stem as the merchantable section, (ii) branches with minimum diameter of $3 \mathrm{~cm}$, and (iii) twigs and leaves. The total fresh weight of each component was determined immediately in the field, using a mechanical weighing scale $(\max .200 \mathrm{~kg}$, precision $100 \mathrm{~g}$ ). For each component, sub-samples weighing 200-3000 g were taken and their fresh weight determined in the field using a digital weighing scale (max. $3 \mathrm{~kg}$, precision $0.5 \mathrm{~g}$ ).

In the field, the stem of each sampled tree was measured according to the Smalian's method for accurate stem volume estimation [33]. The stem of each individual tree was subdivided into billets, and the top end and the lower end of each section was measured for diameter using a caliper. The bole was divided in the following sections: $0.1,0.4,0.7,1,1.3$ and $2 \mathrm{~m}$ length and then followed by intervals of $1 \mathrm{~m}$ until reaching the starting point of canopy of tree. Table 1 shows the descriptive statistics of the sampled trees.

\section{Laboratory measurements}

The dry weight of all sub-samples (belonging to bole stem, branches and foliage) was determined in the laboratory after drying at $75^{\circ} \mathrm{C}$ in an oven to constant weight. The dry weight of each sub-sample was recorded in the laboratory using a digital weighing scale $(\max .3 \mathrm{~kg}$, precision $0.5 \mathrm{~g}$ ). Dry to fresh weight ratio of the subsamples of each tree component was used to determine the dry weight of each tree component. The dry weight of tree components was added together to give the tree total above-ground dry weight (bole stem, branches, and foliage).
After determining the dry weight of each sub-sample of the bole stems, the subsamples were subjected to an additional treatment, in order to determine wood basic density $(W B D)$. The determination of $W B D$ was adapted from the procedure described in Malimbwi et al. [34] and Munishi and Shear [35]. From each stem sub-sample, four square specimens of $3 \times 3 \mathrm{~cm}$ (with the height varying from 3 to $4 \mathrm{~cm}$ depending on the thickness of the stem disk sample) were extracted. Each specimen was submerged in water for a week in order to attain its fresh volume. Each specimen was then submerged in a graduated 1-1 container with the precision of $0.1 \mathrm{~cm}^{3}$ for the estimation of the subsample volume. The WBD of each specimen was obtained by dividing its dry mass (in grams) by its corresponding wet volume (in cubic centimeters) [22,36]. Finally, the $W B D$ of the stem $\left(\mathrm{g} \mathrm{cm}^{-3}\right)$, which is shown in Table 1, was calculated averaging the sum of the ratio dry weight $\left(\mathrm{sdw}_{i} ; \mathrm{g}\right)$ and the volume $\left(\mathrm{sv}_{i}\right.$; $\mathrm{cm}^{-3}$ ) of each of the four specimens was extracted per sub-sample, using Eq. 1.

$$
W B D=\frac{1}{4} \sum_{4}^{i=1} \frac{s d w_{i}}{s v_{i}}
$$

\section{Data analysis \\ Construction of biomass allometric equation and height- diameter regression models}

Six alternative non-linear regression functions were selected as candidate BAE and tested in this study (Table 2). The adequacy of $D B H$ alone (model 4), $D B H$ in combination with total height $(T H)$ (model 1 and 6), $D B H$ in combination with WBD (model 3) and the combination between $D B H, T H$ and $W B D$ (model 2 and 5) as predicting variables of total dry weight $(t D W)$ of standing forest (live trees) were selected as candidate BAE and tested in this study. We also tested the relationship between tree $T H$ and $D B H$. The diameter-height models were selected from Ngomanda et al. [12] (model 7 is a power function and model 8 is Mitscherlisch function) and Mugasha et al. [37] (model 9 and 10), and were fitted using non-linear regression.

\section{Model selection and evaluation criteria}

The BAE and the height-diameter relationship model which showed the lowest value of residual standard error (RSE) and Akaike's information criterion (AIC, Eq. 2) was chosen $[18,37,38,44]$. Both BAE and height-diameter models were develop in $\mathrm{R}$ software, version 3.3.2 [40], using the non-linear least square regression approach in the 'nlstools' package [39]. For further analysis, we computed two other parameters, 
Table 2 Alternative models tested for predicting total above-ground tree biomass (model 1-6) and for predicting total height (model 7-10) in mountain moist evergreen forest of Moribane forest reserve in Mozambique

\begin{tabular}{|c|c|c|}
\hline Model & Expression & Source \\
\hline \multicolumn{3}{|c|}{ Biomass allometric models } \\
\hline 1 & $t D W=b_{0} \times D B H^{b_{1}} \times T H^{b_{2}}$ & Magalhães and Seifert [20] \\
\hline 2 & $t W D=b_{0} \times D B H^{b_{1}} \times T H^{b_{2}} \times W D^{b_{3}}$ & $\begin{array}{l}\text { Ngomanda et al. [12], } \\
\text { Chave et al. [42], } \\
\text { Mugasha et al. [37] }\end{array}$ \\
\hline 3 & $t D W=b_{0} \times D B H^{b_{1}} \times W D^{b_{2}}$ & Mate et al. [15] \\
\hline 4 & $t D W=b_{0} \times(D B H)^{b 1}$ & Guedes et al. [17] \\
\hline 5 & $t D W=b_{0} \times\left(D B H^{2} \times T H \times W D\right)^{b_{2}}$ & $\begin{array}{l}\text { Ngomanda et al. [12], } \\
\text { Chave et al. [42], } \\
\text { Mugasha et al. [37] }\end{array}$ \\
\hline 6 & $t D W=b_{0} \times\left(D B H^{2} \times T H^{b 1}\right)$ & \\
\hline \multicolumn{3}{|c|}{ Diameter-height models } \\
\hline 7 & $T H=1.3+b_{0} \times\left[\exp \left(-b_{1} \times \exp \left(-b_{2} \times D B H\right)\right)\right]$ & Mugasha et al. [37] \\
\hline 8 & $T H=b_{0}-b_{1} \times \exp \left(-b_{2} \times D B H\right)$ & Ngomanda et al. [12] \\
\hline 9 & $T H=1.3+\left[D B H^{2} / b_{0}+b_{1} \times D B H+b_{2} \times D B H^{2}\right]$ & Mugasha et al. [37] \\
\hline 10 & $T H=b_{0} \times D B H^{b_{1}}$ & Ngomanda et al. [12] \\
\hline
\end{tabular}

$t D W$ is total (stem, branches and foliage) dry weight of individual tree $\left(\mathrm{kg} \mathrm{tree}^{-1}\right)$

$D B H$ is diameter at breast height $(\mathrm{cm})$

$T H$ is total height $(\mathrm{m})$

WBD is wood basic density $\left(\mathrm{g} \mathrm{cm}^{-3}\right)$

$b_{0}, b_{1}, b_{2}$ and $b_{3}$ are the regression parameters

as suggested by Kachamba et al. [44], i.e. mean prediction error (MPE, Eq. 3), relative mean prediction error (RMPE, Eq. 4) for all alternative models tested in this study.

$$
\begin{aligned}
& A I C=n \log \left(\sum_{i=1}^{n} \frac{\left(t D W_{e s t, i}-t D W_{o b s, i}\right)^{2}}{n}\right)+2 p \\
& M P E=\frac{\left(t D W_{e s t, i}-t D W_{o b s, i}\right)}{n} \\
& R M P E=\sum_{i=1}^{n} \frac{M P E}{\bar{Y}} \times 100
\end{aligned}
$$

where AIC (unite less) is Akaike's information criterion, MPE is mean prediction error $\left(\mathrm{kg} \mathrm{tree}^{-1}\right)$, RMPE is relative mean prediction error (\%), $t D W_{\text {est }, i}$ and $t D W_{o b s, i}$ are estimated and observed total dry weight of individually weighed tree $i$, respectively, $\bar{Y}$ is average of observed total dry weight $\left(\mathrm{kg} \mathrm{tree}^{-1}\right), n$ is total number of sampled trees, and $p$ is number of parameters in the tested model. All model goodness-of-fit testing were performed in R software, version 3.5.1 [40].

\section{Comparison with existing regression models}

Finally, we compared the performance of prediction of our best BAE developed in this study with the BAE shown in Table 3, which were selected from the literature. We tested three moist forest models of Pan-tropical [22, 41, 42], one rainforest model from Tanzania [43], three lowland miombo woodland, of which one from Tanzania [37] and another model from Mozambique [17]. The comparison was made based on MPE and RMPE [17, 44]. The best model was considered to be the one that yielded the lowest MPE and RMPE value close to our selected biomass model.

\section{Biomass expansion factor}

The BEF was calculated as the average ratio between total dry weight and total stem weight of all harvested trees using Eq. 5 [2, 14, 22, 23].

$$
B E F=\frac{1}{n} \times \sum_{i=1}^{n} \frac{t D W_{i}}{t S W_{i}}
$$

where $B E F$ (unit less) is biomass expansion factor, $t D W,_{i}$ $\left(\mathrm{kg} \mathrm{tree}^{-1}\right)$ is total (bole stem, branches and foliage) dry 
Table 3 Models with diameter at breast height (DBH), total height $(T H)$ and wood basic density (WBD) as independent variables selected from the literature and used to compare with the predictive accuracy of the BAE developed in this study

\begin{tabular}{|c|c|c|c|c|c|c|}
\hline ID no. & Biomass allometric equation & Source & $D B H$ range $(\mathrm{cm})$ & Sampled trees & Forest type & Country \\
\hline 1 & $t D W=\exp (-2.134+2.530 \times \ln (\mathrm{DBH}))$ & Brown [22] & $5-148$ & 170 & Moist forest & Pan-tropical \\
\hline 2 & $\begin{array}{l}t D W=\exp (-2.289+2.649 \times \ln (D B H)) \\
\left.\quad-0.021 \times \ln \left(D B H^{2}\right)\right)^{*}\end{array}$ & Pearson et al. [41] & $5-148$ & 170 & Moist forest & Pan-tropical \\
\hline 3 & $t D W=0.1754 \times D B H^{2.3238}$ & Guedes et al. [17] & $5-53$ & 155 & Miombo woodland & Mozambique \\
\hline 4 & $t D W=0.1014^{*}\left(W B D^{*} D B H^{2 *} T H\right)^{0.9510}$ & Mugasha et al. [37] & $5-100$ & 60 & Miombo woodland & Tanzania \\
\hline 5 & $t D W=0.0673 *\left(W B D^{*} D B H^{2 *} T H\right)^{0.976}$ & Chave et al. [42] & NA & 4004 & Moist forest & Pan-tropical \\
\hline 6 & $t D W=0.1027^{*} D B H^{2.4798}$ & Masota et al. [43] & $5-100$ & 60 & Rainforest & Tanzania \\
\hline
\end{tabular}

NA not available

weight of each individually sampled tree, $t S W,{ }_{i}\left(\mathrm{~kg} \mathrm{tree}^{-1}\right)$ is total dry weight of the bole stem alone and of each individually sampled tree, and $n$ is the total number of sampled trees.

\section{Stem volume}

The stem volume was calculated by using two procedures: (i) the destructive method, i.e. the volume calculated per section using the Smalian's formula (Eq. 6) as used by Henry et al. [45] in a similar study in a moist evergreen forest in Ghana; and (ii) considering the general factor form (Eq. 7), as suggested by Marzoli [4], which is the conventional procedure used to calculate stem volume (merchantable volume) in national forest inventories of native forests in Mozambique. We seek to understand the implication of using the national volume equation from Marzoli [4] against that generated in this study by the sectional method. The Marzoli [4]'s equation was used to predict mean volume per hectare from forest inventory data which was then used for prediction of AGB using BEF.

$$
\begin{aligned}
& V_{c}=\sum_{i=1}^{n}\left(\frac{D_{u}^{2}+D_{b}^{2}}{8} \times L_{i}\right) \\
& V_{c}=\frac{\pi \times D B H^{2}}{4} \times h_{c} \times f_{c}
\end{aligned}
$$

where $V_{c}\left(\mathrm{~m}^{3}\right)$ is stem volume (otherwise merchantable volume), $D B H(\mathrm{~cm})$ is the diameter at breast height of all sampled trees, $D_{b}(\mathrm{~cm})$ is diameter of the lower crosssection, $D_{u}(\mathrm{~cm})$ is that of the upper cross-section; $L(\mathrm{~m})$ is length of stem; $h_{c}(\mathrm{~m})$ is tree commercial height, and $f_{c}$ $(0.8)$ is form factor for merchantable stem volume.
Since the equation suggested by Marzoli [4] takes a constant form factor $\left(f_{c}\right)$ for commercial height of trees, regardless of forest type and tree species differences, in this study we compared the stem volume calculated from the two procedures, under the specific conditions of the moist forest of MFR and using the Wilcoxon's test $(\alpha=0.05)$. By using Marzoli [4]'s equation, we aimed at evaluating the potential to use the BEF combined with the volume tables of the national forest inventory for quick estimates of AGB.

\section{Estimations of total above-ground tree biomass}

The mean AGB was determined using two interchangeable procedures (Eqs. 8 and 9) and by averaging the biomass of the 27 plots sampled in this study. At plot level, biomass was calculated based on Eq. 8, which was developed in this study (Table 3 and Fig. 2), and on Eq. 9, which uses the BEF, mean stand stem volume and WBD. The differences between the two methods were tested using paired samples, two-tailed Wilcoxon test as the AGB from selected model, BEF and Brown's model do not followed Gaussian distribution.

$$
\begin{aligned}
& A G B, j=\left(\frac{0.001}{\text { Area }_{j}}\right) \times \sum_{i=1}^{n}\left(t D W,_{i}\right) \\
& A G B, j=\left(\frac{0.001}{\text { Area }_{j}}\right) \times V_{, j} x W B D \times B E F
\end{aligned}
$$

where $A G B,{ }_{j}\left(\mathrm{Mg} \mathrm{ha}^{-1}\right)$ is above-ground biomass of each sampled plot j; $t D W_{i}\left(\mathrm{~kg} \mathrm{tree}^{-1}\right)$ is total dry weight (bole stem, branches and foliage) of each individually weighed tree at each sampled plot; Area, ${ }_{j}$ (hectares) is the area of each sampled plot ( $0.25 \mathrm{ha}) ; n$ is number of trees found in each plot; 0.001 is a conversion factor from dry weight 

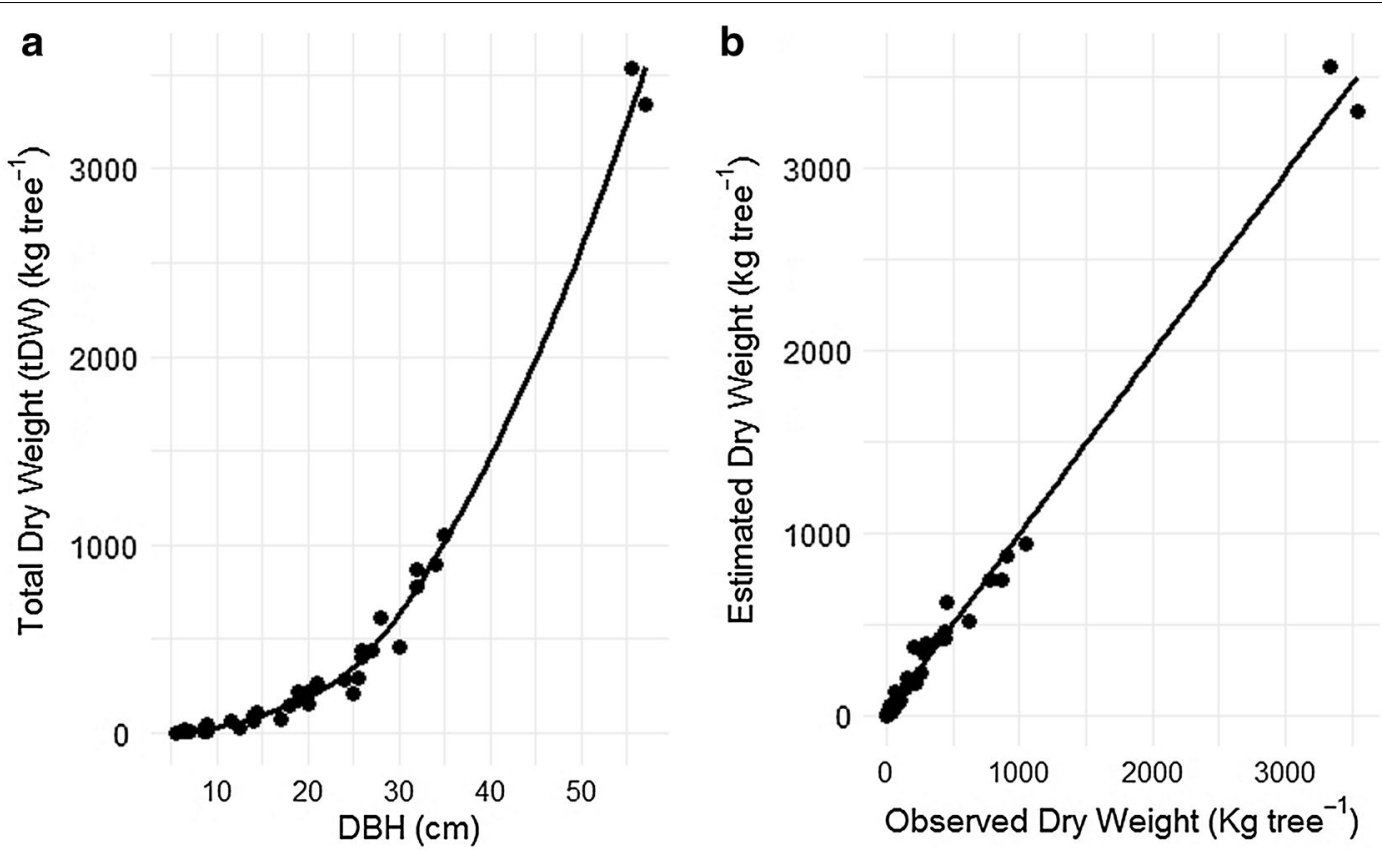

Fig. 2 a Relationship between total above-ground tree dry weight $(\mathrm{kg})$ and diameter at breast height $(\mathrm{DBH})$, according to the power model $t D W=0.0613 \times \mathrm{DBH}^{2.7133}$ fitted in this study; $\mathbf{b}$ relationship between estimated and observed total dry weight tested for the for the 39 trees used to fit the power model above $\left(Y=0.986 X+9.429\right.$, adjusted R-squared 99\%, RMSE $75 \mathrm{~kg} \mathrm{tree}^{-1}, t=61.1$ and $\mathrm{P}<0.0001$, and degrees of freedom 39)

$\left(t D W_{i}\right.$; in kilograms) to $\mathrm{AGB}_{\mathrm{j}} ;\left(\mathrm{Mg} \mathrm{ha}^{-1}\right) ; V_{\mathrm{j}},\left(\mathrm{m}^{3} \mathrm{ha}^{-1}\right)$ is the stand volume according to Marzoli [4]; WBD $\left(\mathrm{Mg} \mathrm{m}^{-3}\right)$ is average wood basic density; and $B E F$ (unit less) is biomass expansion factor.

\section{Results}

Adjusted biomass allometric equation

Parameter estimates and model performance criteria are presented in Table 4 . The model 1 with both $D B H$ and $T H$ and model 2 with $D B H, T H$ and $W B D$, are those with

Table 4 Parameters estimated and statistics of the six candidate regression functions tested to predict total dry weight $(t D W)$ of the moist evergreen forest in MFR in Mozambique

\begin{tabular}{|c|c|c|c|c|c|c|}
\hline \multirow[t]{2}{*}{ Parameter } & \multicolumn{6}{|c|}{ Alternative biomass allometric models } \\
\hline & Model $1^{\text {ab }}$ & Model $2^{\mathbf{b}}$ & Model 3 & Model $4^{b c}$ & Model 5 & Model 6 \\
\hline $\mathrm{AIC}$ & 436 & 438 & 453 & 454 & 533 & 540 \\
\hline RSE (kg tree $\left.{ }^{-1}\right)$ & 61 & 62 & 75 & 77 & 213 & 233 \\
\hline MPE (kg tree $\left.{ }^{-1}\right)$ & -4.7 & -4.9 & -5.1 & -4.3 & -17 & -21.4 \\
\hline RMPE (\%) & -1.2 & -1.2 & -1.3 & -1.1 & -4.3 & -5.4 \\
\hline$b_{0}$ & $0.0912^{* * *}$ & $0.0969^{* * *}$ & $0.0865^{* *}$ & $0.0613^{* * *}$ & $0.0941^{\mathrm{ns}}$ & $0.0441^{\mathrm{ns}}$ \\
\hline $95 \%$ conf. inter. of $b_{0}$ & (0.0603 to 0.1359$)$ & (0.0572 to 0.1597$)$ & (0.0469 to 0.1533$)$ & (0.0378 to 0.0963$)$ & (0.0281 to 0.2716$)$ & (0.0109 to 0.1483$)$ \\
\hline$b_{1}$ & $2.8131^{* * *}$ & $-0.2612^{* * *}$ & $2.6416^{* * *}$ & $2.7133^{* * *}$ & $0.9608^{* * *}$ & $1.0112^{* * *}$ \\
\hline $95 \%$ conf. inter. of $b_{1}$ & (2.7135 to 2.9166$)$ & $(-0.3827$ to -0.1398$)$ & (2.5070 to 2.7857$)$ & (2.5983 to 2.8358 ) & (0.8599 to 1.0750$)$ & (0.8978 to 1.1385$)$ \\
\hline $\mathrm{b}_{2}$ & $-0.2698^{* * *}$ & $2.7945^{* * *}$ & $0.3057^{\mathrm{ns}}$ & & & \\
\hline $95 \%$ conf. inter. of $b_{2}$ & $(-0.3816$ to -0.1583$)$ & (2.6585 to 2.9391$)$ & $(-0.0512$ to 0.6786$)$ & & & \\
\hline$b_{3}$ & & $0.0596^{\mathrm{ns}}$ & & & & \\
\hline $95 \%$ conf. inter. of $b_{3}$ & & $(-0.2468$ to 0.3748$)$ & & & & \\
\hline
\end{tabular}

$T H$ is total height, $R S E$ is residual standard error, $A / C$ is Akaike's information criterion, $b_{0}$ and $b_{1}$ are the regression coefficients

a Equation that fitted better to the data, based on lowest RSE and AIC values

b Equation selected for further analysis

${ }^{* * *}$ significant at $a=0.001,{ }^{* *}$ significant at $a=0.01,{ }^{*}$ significant at $a=0.05, n$ s not statistically significant at $a=0.05$ 

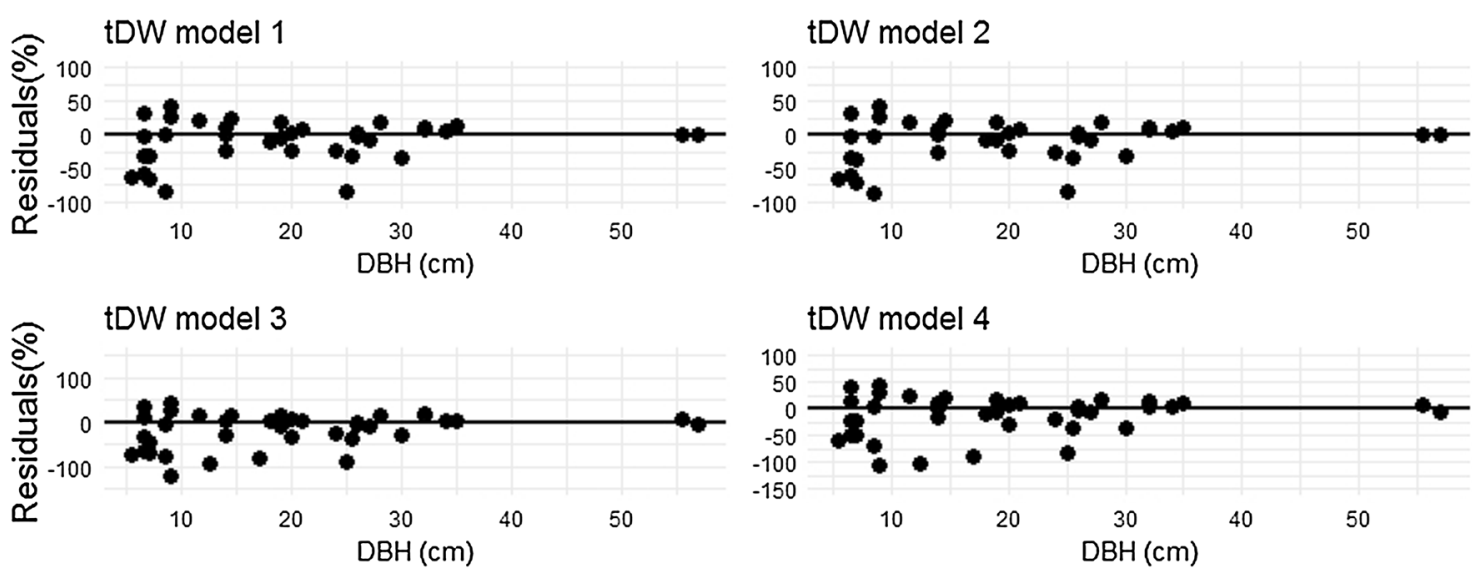

tDW model 4
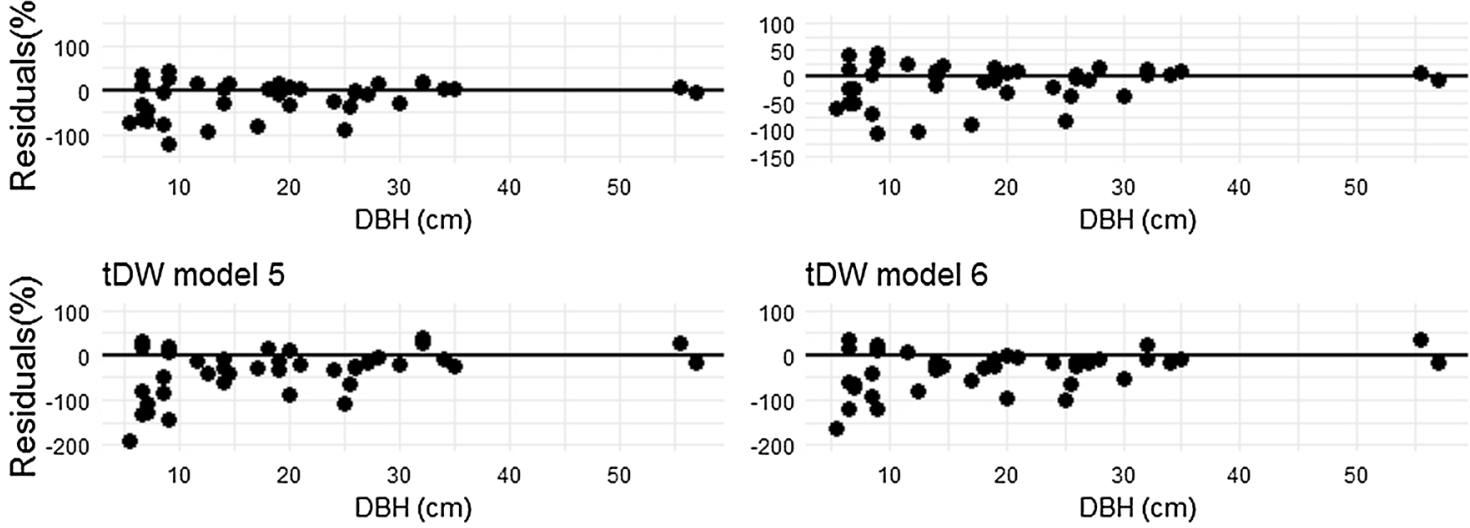

tDW model 6

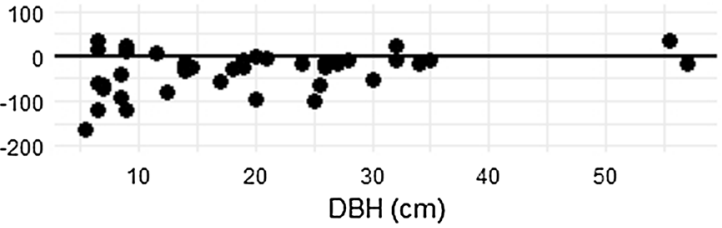

Fig. 3 Relative residuals in the prediction of total aboveground biomass versus DBH for 39 trees in MFR

lower AIC value amongst all fitted models, with 436 and 438 respectively (Table 4 ). The same models performed better in RSE value with 61 and $62 \mathrm{~kg}$ tree $^{-1}$ for model 1 and 2, respectively. However, based on MPE and RMPE, model 4 was the best performing with only $D B H$, but all models generated RMPE but were not statistically significant ( $\mathrm{t}$ test, $\mathrm{P}>0.05$ ). Model 4 had AIC value (454) and RSE (77) almost the same as model 3 (AIC $=453$, $\mathrm{RSE}=75)$ with $D B H$ and $\mathrm{TH}$ as independent variables. All models had negative RMPE values, which means that they are overestimating the $t D W$. Models 5 and 6 are the ones with the highest values of all computed statistics of goodness of fit (AIC, RSE and RMPE). WBD coefficients in model 3 and 2 were not significantly different from zero (t test, $\mathrm{P}>0.05$, Table 4). Adding $T H$ and $W B D$ as a predictor variables to a model with $D B H$ did not improve the performance of the models. Thus, based on AIC, models 1 or 2 were the best than model 4, but given that MPE and RMPE were slightly lower for model 4, this can be shortlisted as candidate best-fitted model (with $\mathrm{MPE}=-4.3 \mathrm{~kg}$ tree ${ }^{-1}$ and $\left.\mathrm{RMPE}=-1.1 \%\right)$.

The model 1, 2 and 4 were selected as the best fits. However the model 4 with only $D B H$ is a candidate for AGB estimation in this study because its variables is in agreement with our data from forest inventory, and it adequately describes the relationship between $t D W$ against $D B H$ (Fig. 2a). The diagnostic of the assumption of linearity between estimated and observed dry weight showed a satisfactory degree of statistical credibility to
Table 5 Predictive accuracy of the $D B H$-based model developed in this study against the models selected from the literature, as compared with observed $t D W$

\begin{tabular}{lcc}
\hline Biomass allometric equation & MAE $\left(\mathbf{k g ~ t r e e}{ }^{\mathbf{- 1}}\right)$ & RMPE (\%) \\
\hline This study (model 4) & -4.2 & -1.1 \\
Brown et al. [22] & -4.9 & -1.2 \\
Pearson et al. [41] & -56.2 & -14.1 \\
Guedes et al. [17] & 110.2 & 27.7 \\
Mugasha et al. [37] & 64.8 & 16.3 \\
Chave et al. [42] & 54.2 & 13.6 \\
Masota et al. [43] & 105.5 & 26.5 \\
\hline
\end{tabular}

justify its use (Fig. 2b). So, the slope of the regression line was significantly different from zero ( $t$ test, $\mathrm{P}<0.0001$ ), which justifies the use of the BAE herein proposed for AGB estimation in the moist evergreen forest of MFR. The residual distribution of each model is presented in Fig. 3, which suggests that model 1, 2, 3 and 4 are all inaccurate but are precise as the scatter dots slightly shifted from zero line, while model 5 and 6 are inaccurate and not precise, as shown in Table 4 and Fig. 3.

\section{Comparison with existing biomass allometric equations}

The BAE found in the literature (Table 3) and tested in this study predicted $t D W$ of sample trees with bias ranged from -1.2 to $55.9 \%$ (Table 5 and Fig. 4). The equation from Brown [22] gave good estimates of AGB at 


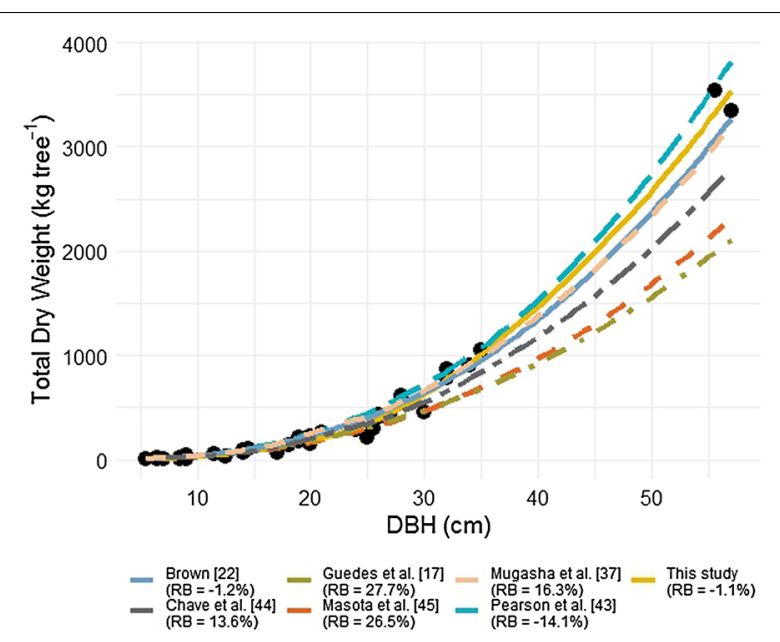

Fig. 4 Graphical visualization of the predictive accuracy of the allometric model developed in this study against those selected from the literature, as compared with observed dry weight

MFR (RMPE $=-1.2 \%$ ). All BAE developed for miombo woodlands underestimated $t D W$ with large difference, and high bias were found to Guedes et al. [17] with 27.7\%. Mugasha et al. [37] from miombo woodland underestimated $t D W$ of moist forest of MFR with $16.6 \%$ bias. Pantropical models of Pearson et al. [41] and Chave et al. [42] had almost the same performance in terms of bias of estimation of $t D W$ with $-14.1 \%$ and $13.6 \%$, respectively. However, Chave et al.s model underestimate the $t D W$, while Pearson et al. [41]'s model overestimate $t D W$ of moist evergreen forest of MFR, although the bias was not statistically significant (t test, $\mathrm{P}>0.05$ ). However, Fig. 3 indicates that Pearson's model is well fitted to the sample data as showing the same trend with Brown's trend line below, beside selected model of this study (model 4). All miombo woodland models are extremely far from trend line of this study. Masota et al. [43]'s trend line is slightly beside all trend line of miombo woodland models (Fig. 4). Thus, based on the results of Table 5 and Fig. 3, Pan-tropical Brown [22]'s model is well fitted to our sample data, and miombo woodland models are not adequate to use in the moist evergreen forest of MFR.

\section{Diameter-height models developed}

The results of height-diameter models performance is presented in Table 6. The height-diameter models suggested that the $T H$ has high correlation with $D B H$ $(r=0.88, \mathrm{P}<0.001)$, which indicates that more than $80 \%$ of variability in $T H$ is explained by $D B H$ (Adj. $\mathrm{R}^{2}=84 \%$, Table 6). The height-diameter model 7 had the lowest AIC and RSE and the power height-diameter model 10 had higher AIC and RSE value amongst all models (Table 6). Model 8 had the lowest MAE and RMPE amongst all tested models, making it the best-fitted model. The estimates of parameters of height-diameter model 8 (Mitscherlisch model) were $\mathrm{b}_{0}=22.4 \mathrm{~m}$ ( \pm standard error: $2.8 \mathrm{~m}$ ) for the asymptotic height, $\mathrm{b}_{1}=20.8 \mathrm{~m}( \pm 2.1 \mathrm{~m})$ for difference between asymptotic and minimum height, and $b_{2}=0.039 \mathrm{~cm}^{-1}$ $\left( \pm 0.012 \mathrm{~cm}^{-1}\right)$ for the shape parameter and had the same AIC value (161) with height-diameter model 9. The asymptotic height reported by model 8 can also be shown in Fig. 5a, which reached the asymptotic height of $20 \mathrm{~m}$ (very close to $22.4 \mathrm{~m}$ from selected model), and the $D B H$ reached $45 \mathrm{~cm}$. However, Fig. $5 \mathrm{~b}$ is showing that $t D W$ is still increasing as a result of tree growth in diameter. Figure $5 \mathrm{a}$ is suggesting that our sampled data covered all range of total tree height of moist forest of MFR. All diameter-height models had good performance based on residuals distribution showed in the Fig. 6 .

Table 6 Parameter estimated of height-diameter relationship with Mitscherlisch model as the best-fitted

\begin{tabular}{|c|c|c|c|c|}
\hline \multirow[t]{2}{*}{ Parameters } & \multicolumn{4}{|c|}{ Diameter-height models tested } \\
\hline & Model 7 & Model 8 & Model 9 & Model 10 \\
\hline $\mathrm{AIC}$ & 160 & 161 & 161 & 163 \\
\hline RSE (kg tree ${ }^{-1}$ ) & 0.84 & 0.84 & 0.83 & 0.82 \\
\hline Adj. $R^{2}$ & 1.79 & 1.8 & 1.81 & 1.87 \\
\hline MPE $\left(\mathrm{kg} \mathrm{tree}^{-1}\right)$ & $3.17 \mathrm{E}-04$ & $1.17 \mathrm{E}-09$ & $1.50 \mathrm{E}-03$ & -0.03 \\
\hline RMPE (\%) & $2.72 \mathrm{E}-03$ & $1.00 \mathrm{E}-08$ & 0.01 & -0.26 \\
\hline$b_{0}$ & $19.1887^{* * *}$ & $22.4381^{* * *}$ & $0.4833^{\text {ns }}$ & $2.4988^{* * *}$ \\
\hline $95 \%$ conf. inter. of $b_{0}$ & (16.3862 to 23.6319$)$ & (18.4177 to 32.4790$)$ & $(-3.8488$ to 6.0111$)$ & (1.8953 to 3.2535$)$ \\
\hline$b_{1}$ & $2.0685^{* * *}$ & $20.7766^{* * *}$ & $1.0296^{* * *}$ & $0.5346^{* * *}$ \\
\hline $95 \%$ conf. inter. of $b_{1}$ & (1.6784 to 2.6690$)$ & (17.2706 to 29.0343$)$ & (0.4104 to 1.5866$)$ & (0.4519 to 0.6192) \\
\hline$b_{2}$ & $0.0690^{* * *}$ & $0.0383^{* *}$ & $0.0343^{* * *}$ & \\
\hline $95 \%$ conf. inter. of $b_{2}$ & (0.0453 to 0.1011$)$ & (0.0179 to 0.0649$)$ & (0.0211 to 0.0495$)$ & \\
\hline
\end{tabular}

*** significant at $a=0.001,{ }^{* *}$ significant at $\alpha=0.01,{ }^{*}$ significant at $a=0.05$, ns not statistically significant at $a=0.05$ 


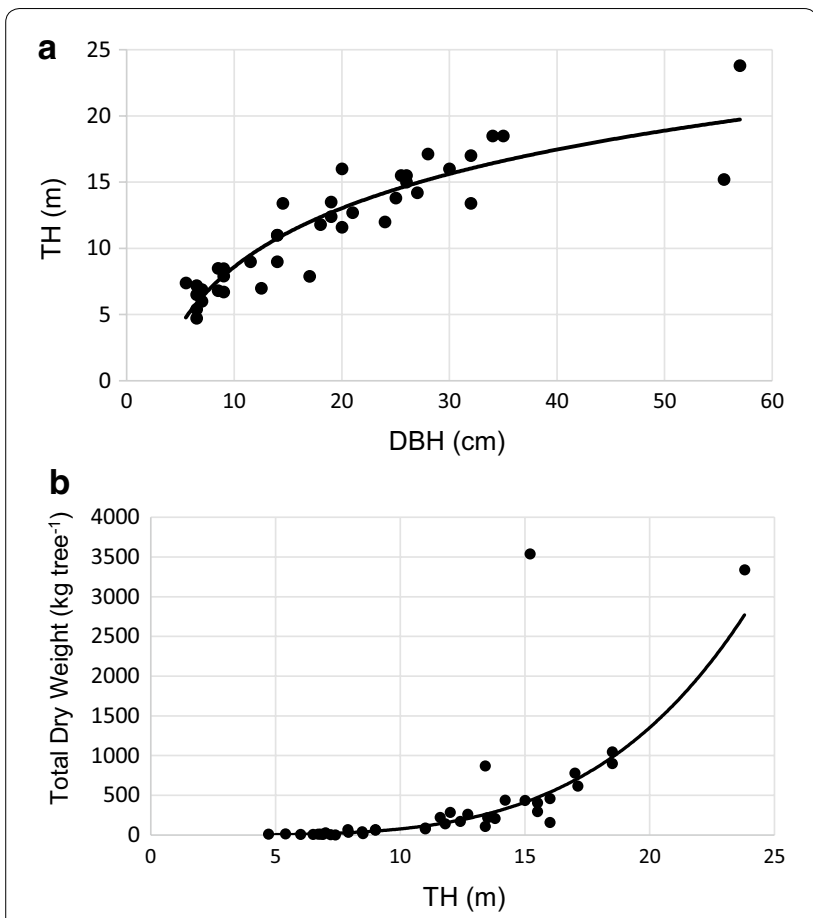

Fig. 5 Relationship between $T H$ and $D B H(\mathbf{a})$ and relationship between $T H$ and $t D W(\mathbf{b})$ of sampled tree data

\section{Biomass expansion factor determined}

The average BEF established for the moist forest of MFR was $2.05 \pm 0.15$ (mean \pm standard error), and the general
WBD suggested for all species of the studied forest was $0.715 \pm 0.018 \mathrm{~g} \mathrm{~cm}^{-3}$. The stem volume, as depicted in Fig. 7, did not differ significantly than the one estimated by the Smalian's formula (paired sample, two-tailed, Wilcoxon test, $\mathrm{P}>0.05)$. Therefore, in the following analyses, this study uses the merchantable volume estimated using Marzoli [4]'s equation to harmonize with the general procedures currently used to estimate stem volume in national and sub national forest inventory reports in Mozambique. The mean merchantable volume estimated from Marzoli [4]'s equation was about $244.84 \pm 79.63 \mathrm{~m}^{3} \mathrm{ha}^{-1}$ (mean $\pm 95 \%$ of confidence level).

\section{Estimations of above-ground biomass}

Total AGB of the mountain moist evergreen forest of MFR, calculated using the BAE fitted in this study, averaged $290.73 \pm 140.80 \mathrm{Mg} \mathrm{ha}^{-1}$ (mean $\pm 95 \%$ of confidence level), and the one calculated by the BEF averaged $386.77 \pm 125.79 \mathrm{Mg} \mathrm{ha}^{-1}$. The BEF method generated significantly higher AGB than biomass model (Wilcoxon test, two-tailed, $\mathrm{P}<0.0001)$. The AGB estimated using Brown's model is somehow providing additional evidence that Brown's model is still applicable to the MFR, and estimated about $247.67 \pm 104.83 \mathrm{Mg} \mathrm{ha}^{-1}$ of AGB, which was not significantly different with the AGB estimated by the selected biomass model of this study (Wilcoxon test, two-tailed, $\mathrm{P}>0.05$ ).

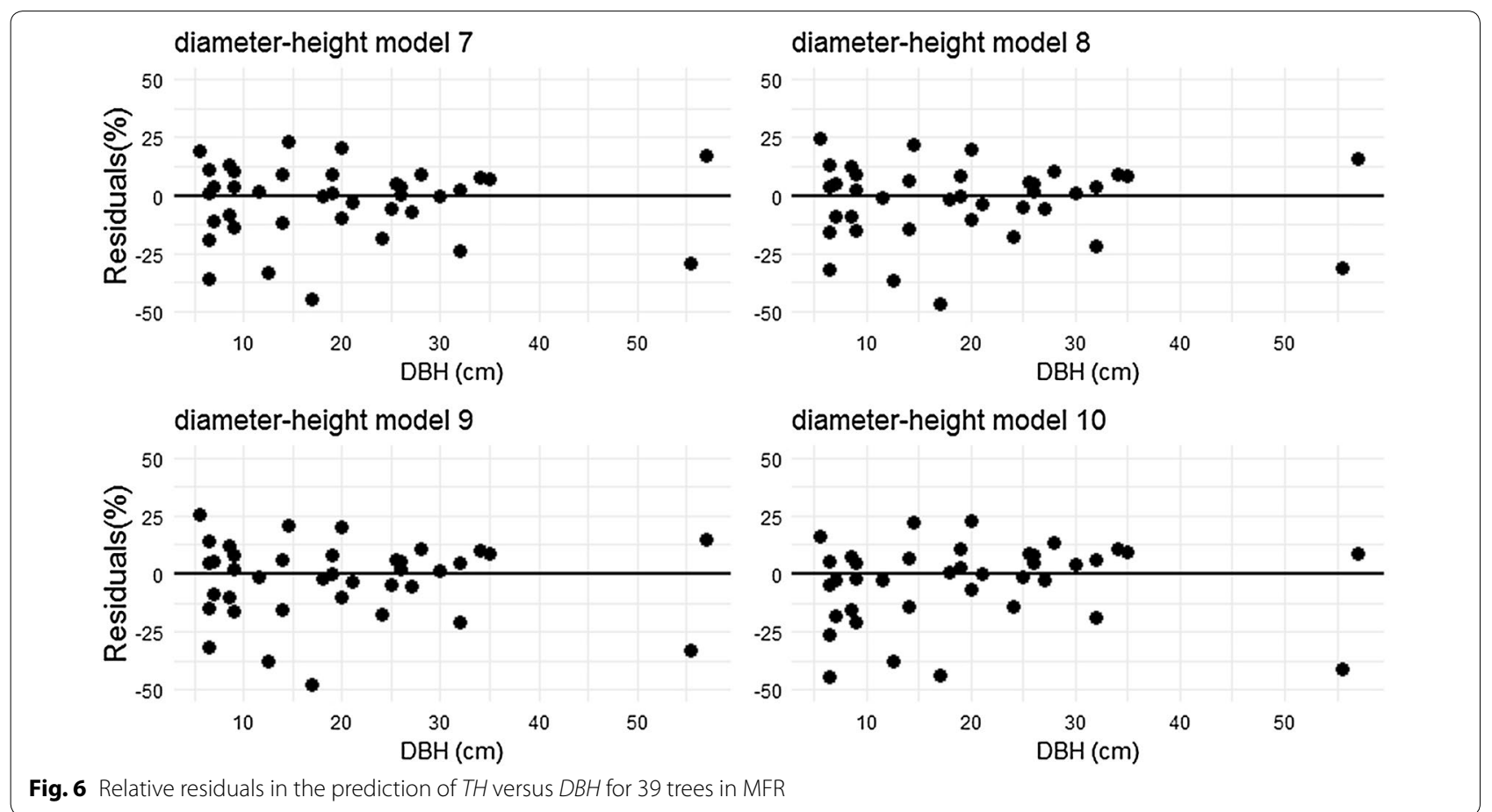



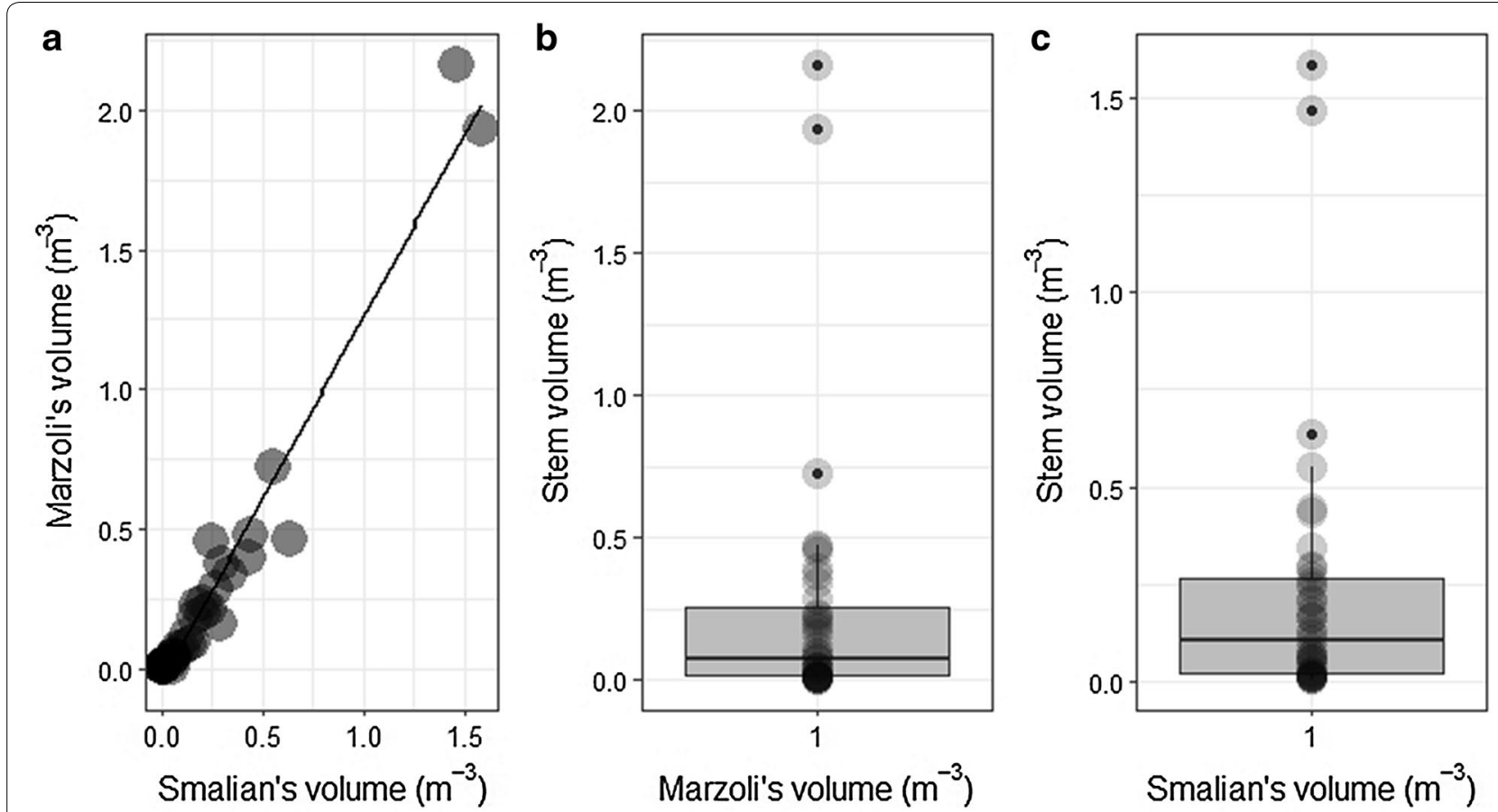

Fig. 7 a Relationship between Smalian's volume and Marzoli [4]'s volume $(Y=-0.0453+1.304 X(Y=1.304-0.0453$, R-squared 96\%, RSE $0.091 \mathrm{~m}^{-3}, \mathrm{P}<0.0001$, and degrees of freedom 37), and (b, c) descriptive statistics and mean comparison between Smalian's volume and Marzoli [4]'s volume generated from sampled trees of MFR. The volume estimated using Smalian's equation and Marzoli's equation did not differ significantly between each other (paired samples, two-tailed, Wilcoxon test, $\mathrm{P}>0.05$ )

\section{Discussion}

\section{Biomass allometric equation}

The BAE was developed for mountain moist evergreen forest in MFR as a tool of biomass estimation and hence, carbon stocks and emissions in Mozambique. The selected BAE (model 4) was consistent with several authors that fitted the same power model with only $D B H$ as a predictor variable $[10,15,22,37,44,46,47]$. The selected model does not include the tree height as a predictor variable, although some studies indicated that including tree height as predictor can improve the performance of model [38, 48, 49]. However, our results showed that the model with both $D B H$ and $T H$ (model 1 and 6) did not improve significantly its performance in comparison with model 4 with only $D B H$.

The most important predictor of volume or AGB is usually $D B H$. Depending on the desired precision and availability of additional predictors, a measurement of height, WBD and an higher diameter can also be included if they significantly reduce the volume prediction error [33]. All tested models indicated that using $D B H, T H$ and $W B D$ with four model parameters had good performance just based on AIC. Adding $T H$ and $W B D$ as a predictor variable to a model with $D B H$ did not improve the performance of the models. This can be seen in Fig. 8, which shows that model 2 with $D B H, T H$ and $W B D$ as predictors overlapped to model 4 with only $D B H$, both models

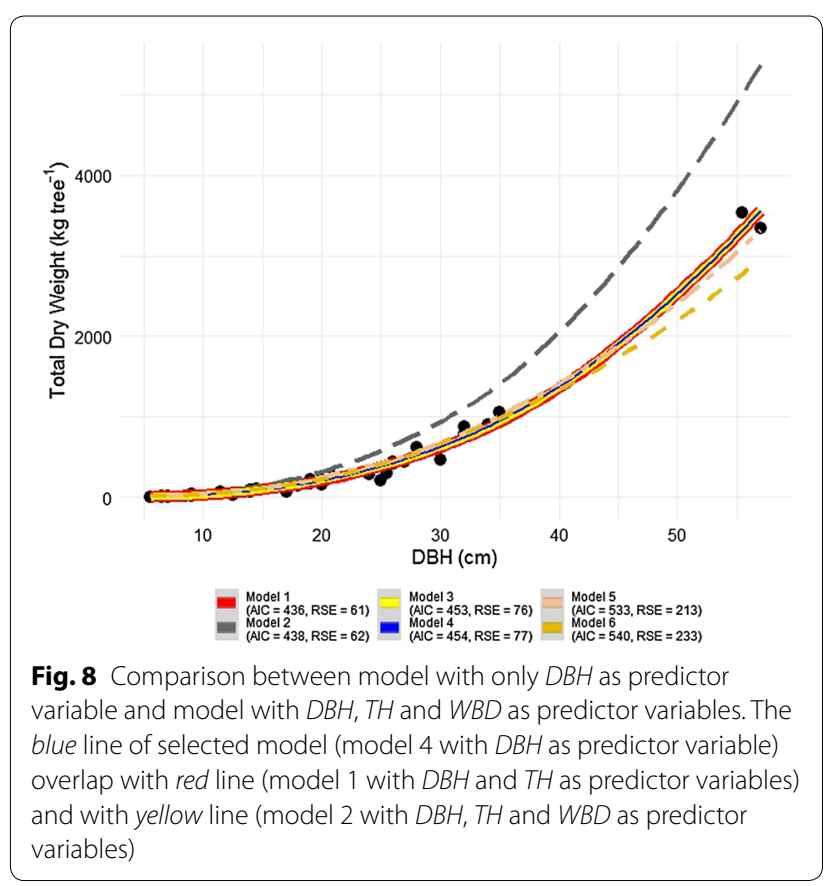


generate $t D W$ which falls into the same confidence interval of $95 \%$.

According to Ebuy et al. [50], a model which depends on $D B H$ only is more appropriate when dealing with forest inventory data. The models (1-6) fitted in this study are commonly used and fitted by researchers [22, 37, $44,46,47]$, however, we selected the model with $D B H$ rather than model 2 with $D B H, T H$ and $W B D$ as both models had the same performance. According to Backer et al. [51], WBD is an important predictor of stand-level AGB, meanwhile, Overman et al. [52], in their study, recommend using the model with $D B H$ only even with the lower goodness of fit relative to the other models fitted with $D B H$ and $W B D$ as predictor variables. This argument has been supported by Ebuy et al. [50], who stated that $W B D$ becomes useful when extensive database exists. In this case, $W B D$ can be used with model 6 to predict AGB of moist evergreen forest of MFR. However, it does not significantly bring any significant added value in accuracy to estimate AGB of the mountain moist evergreen forest, when compared to the single variable model (model 4) selected as the best model that deal with our forest inventory data. Yet, model 2 instead of $D B H$ and $W B D$ has also $T H$ as predictor, and $T H$ is very difficult to assess in closed canopies of MFR. Moreover, the conventional data collection in forest inventory in Mozambique usually estimates, rather than measures, total tree heights. Tree heights in many cases are not recorded in the closed forest such as mountain moist evergreen forest of MFR where the access to canopy is difficult [53].

Where total height is particularly needed for other purposes than estimation of AGB, the diameter-height model 8 (Table 6) developed in this study for TH estimation can be used. For instance, Chave et al. [38] have used tree height model to estimate AGB in pan-tropical moist forest. However, Feldpausch et al. [54] stressed that the integration of tree height into BAE underestimates carbon storage by $13 \%$.

\section{Model comparison with existing models}

Pan-tropical models from Pearson et al. [41], including the allometric model developed by Guedes et al. [17] for a miombo woodland of Mozambique, were compared to our selected model (model 4) which showed differences between two sites. The other pan-tropical model that is mostly used, developed by Chave et al. [42], was compared in this study and it had bias of $13 \%$, suggesting different climatic conditions from the region where it was developed. The relative mean prediction error (RMPE) of Brown [22]'s model of moist tropical forest showed that it can be applicable to predicting AGB in our study area despite not having included tree species from Africa. All models of miombo woodlands [17, 37] and moist forest [43-43] were not applicable to estimate AGB at the mountain moist evergreen forest in Mozambique.

While Brown [22]'s model underestimates somehow the dry weight of trees larger than $35 \mathrm{~cm}$, it generates estimation with the relative bias of $1.2 \%(P<0.05)$ close to those generated by the best-fitted model of this study with the relative bias of $1.1 \%(P>0.05)$. On the other hand, Pearson's model estimated lower AGB with a relative bias of $26.60 \%(P<0.01)$. Differences between BAE could also result from regional differences in diameterheight allometry [55]. The tree allometry could be the key source of the differences found, as mountain moist evergreen forest are typically tall trees that may grow much more than $20 \mathrm{~m}$, while lowland miombo is dominated by shorter trees for the same diameter, which justifies lower dry weight for trees in these woodlands. Eventually, the allometry of the trees in the Brown's sample may have included trees with similar allometry to the trees of our study area, although Brown's model consistently predicted lower AGB than our selected model. Gibbs et al. [13] argued that the effort required to develop species or site-specific BAE would not typically improve accuracy in AGB estimations. Contrary to the results of Gibbs et al. [13], our results on existing model performance is in part in agreement with what was found by Ngomanda et al. [12], who stated that the pan-tropical equations currently do not correctly capture the variability of biomass allometry at the global scale. This can be seen with tested pantropical models (Pearson et al. [41]'s model and Chave et al. [42]'s model, Table 5 and Fig. 4).

\section{Estimation of the biomass expansion factor}

The average $W B D$ found in this study can be comparable with those found in lowland tropical rain forest in Costa Rica (range from 0.27 to $0.74 \mathrm{~g} \mathrm{~cm}^{-3}$ ) [36]. Muller-Landau et al. [36] indicate that for biomass calculations, site average $W B D$ values should ideally be weighted by wood volume. The values of BEF found in this study were not statistically different from those obtained by Machoco [16], for lowland miombo woodlands of the Central Mozambique, with values ranging from 1.20 to 5.09 and averaging $2.03 \pm 0.14$. We would expect BEF from mountain moist evergreen forests to be lower than that of lowland Miombo woodlands. However, the lack of differences can be due to the data sources. Machoco [16] used average $W B D$ obtained from the literature while in this study we used direct measurements through destructive sampling.

The BEF obtained in this study was much smaller compared to the moist central African forest reported by Ngomanda et al. [12] with 1.55 (range: 1.04 and 5.59), obtained by Segura and Kaninnen [23] in tropical humid forest of Costa Rica (mean 1.60 \pm 0.20 ranging from 1.4 
to 1.9), and reported by Henry et al. [45] in Ghana (mean 1.51, range: 1.13 to 2.20 ) or by Djomo et al. [48] in southeast Cameroon (mean 1.22, range: 1.02 to 2.02). This is probably because of differences in biomass allocation among different tree components, in diameter-height tree allometry and the crown architecture in different regions $[12,55]$. The BEF estimate at MFR was lower than the value of 3.4 reported by the IPCC for tropical forest stands, but it was consistent with that found by Brown and Lugo [2] with an average range from 1.1 to 2.5, obtained from the forests of Africa, America, and Asia. Brown [56] states that tropical forests tend to have higher $\mathrm{BEF}$ for a given volume and tree size reflecting the large size of the tree crowns when compared to those of temperate forests. Brown et al. [24] estimated different BEF for primary, secondary and non-productive rainforest of Sri Lanka, and presented average values around 2.02, 2.26 and 4.48, respectively. According to those values, the BEF found in this study is within primary to secondary forest, perhaps because of high level of human disturbance which makes the forest in MFR more of a transition mountain moist evergreen forest with typically large crowns than in an undisturbed forest.

\section{Estimation of above-ground biomass}

The models of above-ground tree biomass (AGB) in this study were developed using data with $D B H$ range from 5 to $57 \mathrm{~cm}$. However, according to the forest inventory data, the maximum $D B H$ of the trees recorded in the study area was $179 \mathrm{~cm}$. Thus, including individual trees with bigger size than $57 \mathrm{~cm}$ would be necessary in the future to ensure the representativeness of individual's trees in the ecosystem. The study was carried out in a conservation area where national legislation does not allow logging activities. With this limitation, the sample trees were cut in the buffer zone of MFR, where human disturbance is high. Consequently, there was lack of large size trees $(D B H>40 \mathrm{~cm})$, and this was also recorded during the forest inventory inside the protected area.

The fitted models should be used with caution with large trees $(D B H>57 \mathrm{~cm})$ because they can overestimate the AGB. In this sense, a comparison of AGB was made between the model of this study and Brown's for mountain moist evergreen forest, however, there is no significant difference between AGB estimates from the two models (Fig. 9). This indicates that the BAE of this study estimates AGB as expected for moist evergreen forest, regardless of the size of the trees of fit. It should be noted that both models generate over-estimate total above ground tree dry weight for larger trees $(D B H>100 \mathrm{~cm})$, as it can be seen in Fig. 9, where all plots with trees larger than $100 \mathrm{~cm}$ became an outlier, trees with $D B H>100 \mathrm{~cm}$ accounting for $39 \%$ of the AGB, 18 trees with $D B H$ above $100 \mathrm{~cm}, 33$ trees with $D B H$ ranging from 60 to $100 \mathrm{~cm}$, 2634 trees with $D B H<60 \mathrm{~cm}$, and 2685 trees were measured in inventory forest.

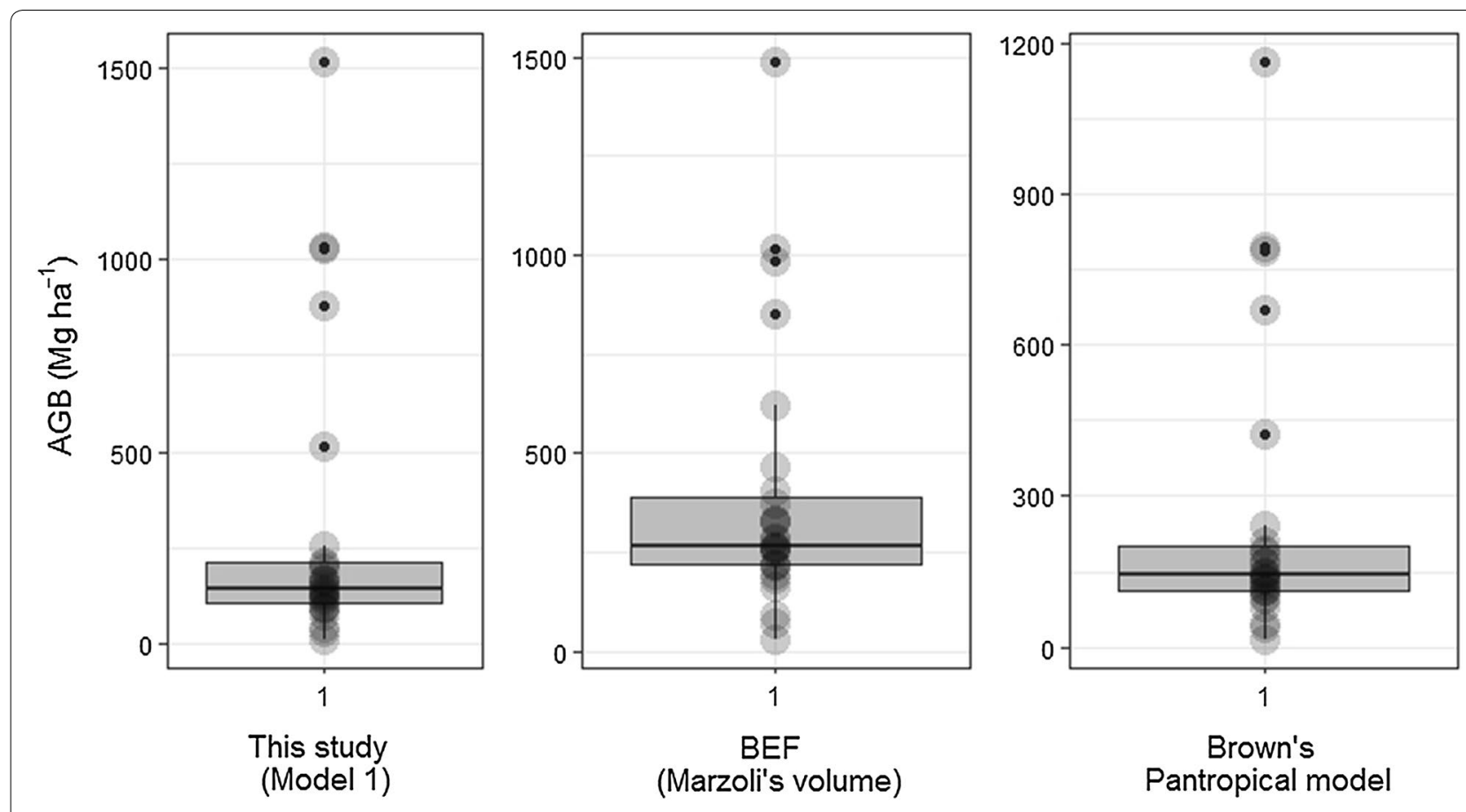

Fig. 9 Above-ground biomass estimated by selected biomass allometric model and BEF of this study as well as Pan-tropical model of Brown [22] 
The main purpose of Marzoli's volume equation application is to explore the possibility of using the volumes table from the national forest inventory generated by Marzoli [4] so that they are used to convert AGB through the BEF. Figure 7 shows that the Smalian's volume was not different with Marzoli's volume of sampled trees (paired sample, two-tailed, Wilcoxon test, $P>0.05$ ). Thus, the volumes table of Marzoli [4] can be converted to AGB of the forest of the study area using the BEF developed in this study, as shown in Fig. 9 below. Here, there is enough evidence that the BEF overestimates the AGB of the study area and BAE becomes more accurate than BEF.

The mean values of AGB obtained in this study for model 4, BEF and Brown [22]'s model had high variability among plots, as seen for large confidence intervals. Many factors can explain the variability of AGB [heterogeneity of landscape (mature stand forest and secondary forest), soil fertility, wood basic density, high diameter and other factor] [51, 54, 55]. In general, the AGB estimated from selected model $1\left(290.73 \mathrm{Mg} \mathrm{ha}^{-1}\right)$ and from the developed BEF (386.77 $\mathrm{Mg} \mathrm{ha}^{-1}$ ) of this study indicated that the mountain moist evergreen forest stores up to four times more carbon than miombo woodlands of southern Africa lowland, and in agreement with Desanker et al. [57], who state that the AGB in dry miombo woodland is usually low, and is about $55 \mathrm{Mg} \mathrm{ha}^{-1}$ (ranging between 21 and $84 \mathrm{Mg} \mathrm{ha}^{-1}$ ), while for wet miombo woodland it is about $90 \mathrm{Mg} \mathrm{ha}^{-1}$, ranging between 44 and $144 \mathrm{Mg} \mathrm{ha}^{-1}$.

The mean AGB estimated with BEF overestimates the AGB of the study area, in part, because of the overestimation observed with Marzoli's volume. Moreover, the AGB from BEF is within the range reported by Maniatis and Mollicone [58] in three forest types in the Congo Basin forest (AGB ranging from 312 to $333 \mathrm{Mg} \mathrm{ha}^{-1}$ ). Munishi and Shear [35] reported an AGB of about $1055 \pm 35 \mathrm{Mg} \mathrm{ha}^{-1}$ and $790 \pm 20 \mathrm{Mg} \mathrm{ha}^{-1}$, for the evergreen mountain undisturbed forests of Usambaras sand Ulugurus Forest Reserves (highlands, MAP 2900$4000 \mathrm{~mm}$ and lowlands with MAP 1200-3100 mm) respectively, in Tanzania. These values are higher than those found in this study, which could be related to the higher level of human disturbance in MFR. According to Ryan et al. [8], human activities such as agriculture, charcoal production, and timber collection are responsible for about 46 and $56 \%$ of total biomass loss in Sussundenga District, where MFR is located.

\section{Conclusions}

The main objective of this study was to develop a BAE and BEF for AGB estimation in mountain moist evergreen forest of MFR in Mozambique as a step forward for REDD + . The power model with only $D B H$ was selected as the best fit for the whole tree dry weight $(t D W)$ of mountain moist evergreen forest of MFR. This model presented a combination of lower RMSE, although slightly high AIC compared to the alternative candidate models evaluated. In contrary to global model [42, 59], WBD did not improve the performance of models in all tested models. Total height seems to be a powerful predictor variable when combined with $D B H$, but it had at least the same statistical performance with the model with only $D B H$. Thus, we recommend the model with only $D B H$ as predictor instead of that with $D B H, T H$ and WBD together. The comparison using global models showed that the selected model for this study was more accurate for trees sized out of the fit data, suggesting that the selected model is reliable and can be used to estimate AGB in the study area with the same level of accuracy as the global model, and it has potential to be applied in other mountain regions in Mozambique, where mountain moist evergreen forests occur. However, our model could be improved with more data, particularly with larger size trees, but such trees are protected by the law of conservation areas in Mozambique. The BEF of this study can be applied to predict AGB through converting the volume table from national forest inventory developed by Marzoli [4], however, BEF overestimate the AGB. This study suggests that despite being a disturbed conservation area, the MFR still has a large stock of carbon comparable with the mountain moist evergreen forest in the world, but with significant variability of AGB between plots. Therefore, mountain most evergreen forest has a huge potential to provide financial resources through $\mathrm{C}$-based payment for ecosystem services under REDD+ mechanism.

\section{Abbreviations}

BAE: biomass allometric equation; REDD+: Reduction of Emission from Deforestation and Degradation; BEF: biomass expansion factor; AGB: above-ground tree biomass; $D B H$ : diameter at breast height; $\mathrm{tDW}$ : total tree dry weight; $T H$ : total height.

\section{Authors' contributions}

SNL data collection and analysis, article lead writer. BSG data analysis and interpretations, article writing. NR collaboration in study conception, data analysis and article writing. AS study conception, data analysis and interpretations, article writing. All authors read and approved the final manuscript.

\section{Acknowledgements}

The authors acknowledge the contribution by Serviços Provinciais de Florestas e Fauna Bravia de Manica in identifying the area for data collection. We also thank Dr. Emily Woollen and Dr. Sophia Baumert for the manuscript revision.

Competing interests

The authors declare that they have no competing interests.

\section{Availability of data and materials}

All authors declare that the datasets used in this manuscript are available upon request. 


\section{Consent for publication}

Not applicable.

\section{Ethics approval and consent to participate}

Not applicable.

\section{Funding}

This study was funded by the Fundo Nacional de Investigação (FNI).

\section{Publisher's Note}

Springer Nature remains neutral with regard to jurisdictional claims in published maps and institutional affiliations.

Received: 18 November 2017 Accepted: 16 November 2018 Published online: 26 November 2018

\section{References}

1. Russell AE, Raich JW, Arrieta RB, Valverde-Barrantes O, González E. Impacts of individual tree species on carbon dynamics in a moist tropical forest environment. Ecol Appl. 2010:20(4):1087-100.

2. Brown S, Lugo AE. Aboveground Biomass estimates for tropical moist forests of the Brazilian Amazon. Interciencia. 1992;17:1.

3. Soepadmo E. Tropical rain forests as carbon sinks. Chemosphere. 1983;27(6):1025-39.

4. Marzoli A. Inventário Florestal Nacional. Maputo: Relatório Final; 2007.

5. Aicher C. Discourse practices in environmental governance: social and ecological safeguards of REDD. Biodivers Conserv. 2014;23(14):3543-60.

6. Müller T, Sitoe A, Mabunda R. Assessment of the forest reserve network in Mozambique. Technical report. Maputo. 2005.

7. Guedes BS. Caracterização Silvicultural e Comparação das Reservas Florestais de Maronga, Moribane e Zomba, Província de Manica. Forestry Monograph: Universidade Eduardo Mondlane; 2004.

8. Ryan CM, Berry NJ, Joshi N. Quantifying the causes of deforestation and degradation and creating transparent REDD+ baselines: a method and case study from central Mozambique. Appl Geogr. 2014;53:45-54.

9. GoM. Estratégia Nacional para a Redução de Emissões de Desmatamento e Degradação Florestal, Conservação de Florestas e Aumento de Reservas de Carbono Através de Florestas (REDD+). 2016-2030. http://redd.org. mz/uploads/SaibaMais/ConsultasPublicas/ESTRAT\%C3\%89GIA\%20NAC IONAL\%20DO\%20REDD+.pdf. Accessed 10 July 2018.

10. Mugasha WA, Eid T, Bollandsås OM, Malimbwi RE, Chamshama SAO, Zahabu E, Katani JZ. Allometric models for prediction of above- and belowground biomass of trees in the miombo woodlands of Tanzania. For Ecol Manag. 2013:310:87-101.

11. United Nations Framework Conservation on Climate Change (UNFCCC). Paris Agreement. 2015. http://unfccc.int/files/essential_background/ convention/application/pdf/english_parisagreement.pdf. Accessed 10 July 2018.

12. Ngomanda A, Obiang NLE, Lebamba J, Mavouroulou QM, Gomat $H_{\text {, }}$ Mankou GS, Loumeto J, Iponga DM, Ditsouga FK, Koumba RZ, Bobé KHB, Okouyi CM, Nyangadouma R, Lépengué N, Mbatchi B, Picard N. Site-specific versus pantropical allometric equations: which option to estimate the biomass of a moist central African forest? For Ecol Manag. 2014;312:1-9.

13. Gibbs HK, Brown S, Niles JO, Foley JA. Monitoring and estimating tropical forest carbon stocks: making REDD a reality. Environ Res Lett. 2007;2:13.

14. Somogyi Z, Cienciala E, Makipaa R, Muukkonen P, Lehtonen A, Weiss P. Indirect methods of large-scale forest biomass estimation. Eur J For Res. 2007;126(2):197-207.

15. Mate $R$, Johansson T, Sitoe A. Biomass equations for tropical forest tree species in Mozambique. Forests. 2014;5(3):535-56.

16. Machoco RS, Factor de Expansão de Biomassa Florestal na Região do Corredor da Beira. B.Sc thesis, Universidade Eduardo Mondlane. 2008.

17. Guedes BS, Sitoe AA, Olsson BA. Allometric models for managing lowland miombo woodlands of the Beira corridor in Mozambique. Glob Ecol Conserv. 2018:13:e00374.

18. Sitoe AA, Mandlate LJC, Guedes BS. Biomass and carbon stocks of Sofala Bay mangrove forests. Forests. 2014;5(8):1967-81.
19. Magalhães TM. Live above-and belowground biomass of a Mozambican evergreen forest: a comparison of estimates based on regression equations and biomass expansion factors. For Ecosyst. 2016;2:28. https://doi. org/10.1186/s40663-015-0053-4.

20. Magalhães TM, Seifert T. Tree component biomass expansion factors and root-to-shoot ratio of Lebombo ironwood: measurement uncertainty. Carbon Balance Manag. 2015;10(1):1-14.

21. Magalhães TM, Seifert T. Estimation of tree biomass, carbon stocks, and error propagation in mecrusse woodlands. Open J For. 2015;5(4):471-88. https://doi.org/10.4236/ojf.2015.54041.

22. Brown S. Estimating biomass and biomass change of tropical forest. FAO Forestry Paper. Rome: Food and Agriculture Organization; 1997.

23. Segura M, Kanninen M. Allometric models for tree volume and total aboveground biomass in a tropical humid forest in Costa Rica. Biotropica. 2005;37(1):2-8

24. Brown S, Gillespie AJR, Lugo AE. Biomass estimation methods for tropical forests with applications to forest inventory data. For Sci. 1989:35(4):881-902

25. Hewson J, Steininger MK, Pesmajoglou S, editors. REDD+ measurement, reporting and verification (mrv) manual, version 2.0. USAID-supported Forest Carbon, Markets and Communities Program. Washington, DC, USA 2014.

26. e Sousa AG. Reservas Florestais de Moçambique. Instituto de Investigação Agronómica de Moçambique. Comunicação N. 10. Apartado 431. Lourenço Marques. 1968

27. INE. Divulgação dos Resultados Preliminares do Censo 2017. Maputo. 2018

28. Ghiurghi A, Dondeyne S. Chimanimani national reserve: management plan. Rome. 2010

29. Dutton T, Dutton E. Reconhecimento Preliminar das Montanhas de Chimanimani e Zonas Adjacentes a Criação duma Área de Conservação. Loureço Marques: Repartição Técnica da Fauna de Moçambique, Direcção dos Serviços de Veterinária; 1973.

30. Monteiro J, Dondeyne S, Wursten B, Bannerman J, Meilby H, Sitoe A. Vegetation composition of natural gaps in Moribane forest (Mozambique). Afr J Ecol. 2011:49(4):510-4

31. Seabra LR. Solos, Clima e Vegetação do Bloco de Sussundenga. Relatório Final do curso de Engenheiro Silvicultor. Universidade Técnica de Lisboa. 1961

32. Gouveia D, Marques M. Carta de solos de Moçambique. Lourenço Marques: INIA-DTA; 1972.

33. Köhl M, Magnussen SS, Marchetti M. Sampling methods, remote sensing and GIS multiresource forest inventory. New York: Springer; 2006.

34. Malimbwi RE, Solberg B, Luoga E. Estimation of biomass and volume in miombo woodland at Kitulangalo Forest Reserve, Tanzania. J Trop For Sci. 1994;7(2):230-42.

35. Munishi TH, Shear PKT. Carbon storage in afromontane rain forests of the Eastern Arc mountains of Tanzania: their net contribution to atmospheric carbon. J Trop For Sci. 2004;16(1):78-93.

36. Muller-Landau HC. Interspecific and inter-site variation in wood specific gravity of tropical trees. Biotropica. 2004;36(1):20-32.

37. Mugasha WA, Mwakalukwa EE, Luoga E, Malimbwi RE, Zahabu E, Silayo DS, Sola G, Crete P, Henry M, Kashindye A. Allometric models for estimating tree volume and aboveground biomass in lowland forests of Tanzania. Int J For Res. 2016. https://doi.org/10.1155/2016/8076271.

38. Chave TJ, Andalo C, Brown S, Cairns MA, Chambers JQ, Eamus D, Folster H, Fromard F, Higuchi N, Kira T, Lescure JP, Nelson BW, Ogawa H, Puig H, Riera B, Yamakura. Tree allometry and improved estimation of carbon stocks and balance in tropical forests. Oecologia. 2005;145:87-99.

39. Baty F, Ritz C, Charles S, Brutsche M, Flandrois JP, Delignette-Muller ML. A toolbox for nonlinear regression in R: the package nlstools. J Stat Softw. 2015:66(5):1-21.

40. R Core Team. R: a language and environment for statistical computing. Vienna: R Foundation for Statistical Computing; 2016. http://www.R-proje ct.org/.

41. Pearson T, Walker S, Brown S. Sourcebook for land use, land use change and forestry projects. Arlington: Winrock International; 2005.

42. Chave J, Rejou-Mechain M, Burquez A, Chidumayo E, Colgan M, Delitt W, Duque A, Eid T, Fearnside P, Goodman R, Henry M, Martinez-Yrizar A, Mugasha W, Muller-Landau H, Mencuccini M, Nelson B, Ngomanda A Nogueira E, Ortiz-Malavassi E, Pelissier R, Ploton P, Ryan C, Saldarriaga 
J, Vieilledent G. Improved allometric models to estimate the aboveground biomass of tropical trees. Glob Change Biol. 2014. https://doi. org/10.1111/gcb.12629.

43. Masota AM, Zahabu E, Malimbwi RE, Bollandsås OM, Eid TH. Volume models for single trees in tropical rainforests in Tanzania. J Energy Nat Resour. 2014;3(5):66-76.

44. Kachamba DJ, Eid T, Gobakken T. Above- and belowground biomass models for trees in the miombo woodlands of Malawi. Forests. 2016;7:38.

45. Henry M, Besnard A, Asante WA, Eshun J, Adu-bredu S, Valentini R, Bernoux M, Saint-andré L. Wood density, phytomass variations within and among trees, and allometric equations in a tropical rainforest of Africa. For Ecol Manag. 2010;260(8):1375-88.

46. Mwakalukwa EE, Meilby H, Treue T. Volume and aboveground biomass models for dry miombo woodland in Tanzania. Int J For Res. 2014;2014:1-11.

47. Chidumayo E. Estimating tree biomass and changes in root biomass following clear-cutting of Brachystegia-Julbernardia (miombo) woodland in central Zambia. Environ Conserv. 2013:41(1):54-63.

48. Djomo AN, Ibrahima A, Saborowski J, Gravenhorst G. Allometric equations for biomass estimations in Cameroon and pan moist tropical equations including biomass data from Africa. For Ecol Manag. 2010;260(10):1873-85.

49. Nam VT, Van Kuijk M, Anten NPR. Allometric equations for aboveground and belowground biomass estimations in an evergreen forest in Vietnam. PLOS ONE. 2016;11(6):6-9.

50. Ebuy J, Lokombe JP, Ponette Q, Sonwa D, Picard N. Allometric equation for predicting aboveground biomass of three tree species. J Trop For Sci. 2011;23(2):125-32.

51. Baker TR, Phillips OL, Malhi Y, Almeida S, Arroyo L, Di Fiore A, Erwin T, Killeen T, Laurance S, Laurance W, Lewis S, Lloyd J, Monteagudo A, Neill D, Patino S, Pitman N, Silva N, Martinez R. Variation in wood density determines spatial patterns in Amazonian forest biomass. Glob Change Biol. 2004;10:545-62.

52. Overman J, Witte H, Saldarriaga J. Evaluation of regression model for above-ground biomass determination in Amazon Rainforest. J Trop Ecol. 1994;10(2):207-18.

53. Hein L, van der Meer PJ. REDD+ in the context of ecosystem management. Curr Opin Environ Sustain. 2012;4(6):604-11.
54. Feldpausch TR, Lloyd J, Lewis SL, Brienen RJW, Gloor M, Monteagudo Mendoza A, Lopez-Gonzalez G, Banin L, Abu Salim K, Affum-Baffoe K, Alexiades M, Almeida S, Amaral I, Andrade A, Aragão LEOC, Araujo Murakami A, Arets EJM, Arroyo L, Aymard CGA, Baker TR, Bánki OS, Berry NJ, Cardozo N, Chave J, Comiskey JA, Alvarez E, De Oliveira A, Di Fiore A, Djagbletey G, Domingues TF, Erwin TL, Fearnside PM, França MB, Freitas MA, Hiquchi N, Honorio EC, lida Y, Jiménez E, Kassim AR, Killeen TJ, Laurance WF, Lovett JC, Malhi Y, Marimon BS, Marimon Junior BH, Lenza E, Marshall AR, Mendoza C, Metcalfe DJ, Mitchard ETA, Neill DA, Nelson BW, Nilus R, Nogueira EM, Parada A, Peh KS-H, Pena Cruz A, Peñuela MC, Pitman NCA, Prieto A, Quesada CA, Ramírez F, Ramírez Angulo H, Reitsma JM, Rudas A, Saiz G, Salomão RP, Schwarz M, Silva N, Silva-Espejo JE, Silveira M, Sonké B, Stropp J, Taedoumg HE, Tan S, Ter Steege H, Terborgh J, Torello-Raventos M, Van Der Heijden GMF, Vásquez R, Vilanova E, Vos VA, White L, Willcock S, Woell H, Phillips OL. Tree height integrated into pantropical forest biomass estimates. Biogeosciences. 2012;9(8):3381-403.

55. Banin L, Feldpausch TR, Phillips OL, Baker TR, Lloyd J, Affum-Baffoe K, Arets EJMM, Berry NJ, Bradford M, Brienen RJW, Davies S, Drescher M, Higuchi N, Hilbert DW, Hladik A, lida Y, Salim KA, Kassim AR, King DA, Lopez-Gonzalez G, Metcalfe D, Nilus R, Peh KSH, Reitsma JM, Sonké B, Taedoumg H, Tan S, White L, Wöll H, Lewis SL. What controls tropical forest architecture? Testing environmental, structural and floristic drivers. Glob Ecol Biogeogr. 2012;21(12):1179-90

56. Brown S. Measuring carbon in forests: current status and future challenges. Environ Pollut. 2002;116:363-72.

57. Desanker PV, Frost PGH, Justice CO, Scholes RJ. The miombo network: framework for a terrestrial transect study of land-use and land-cover change in the miombo ecosystems of central Africa. In: Conclusions of the Miombo network workshop Zomba, Malawi. 1995.

58. Maniatis D, Mollicone D. Options for sampling and stratification for national forest inventories to implement REDD+ under the UNFCCC. Carbon Balance Manag. 2010;5(1):9.

59. Fayolle A, Doucet JL, Gillet JF, Bourland N, Lejeune P. Tree allometry in Central Africa: testing the validity of pantropical multi-species allometric equations for estimating biomass and carbon stocks. For Ecol Manag. 2013;305:29-37.
Ready to submit your research? Choose BMC and benefit from:

- fast, convenient online submission

- thorough peer review by experienced researchers in your field

- rapid publication on acceptance

- support for research data, including large and complex data types

- gold Open Access which fosters wider collaboration and increased citations

- maximum visibility for your research: over $100 \mathrm{M}$ website views per year

At $\mathrm{BMC}$, research is always in progress.

Learn more biomedcentral.com/submissions 